\title{
CD137-mediated immunotherapy for allergic asthma
}

\author{
Tobias Polte, ${ }^{1,2}$ Juergen Foell, ${ }^{3}$ Christoph Werner, ${ }^{1}$ Heinz-Gerd Hoymann, ${ }^{4}$ Armin Braun, ${ }^{4}$ \\ Stefan Burdach, ${ }^{5}$ Robert S. Mittler, ${ }^{6}$ and Gesine Hansen ${ }^{1}$
}

\begin{abstract}
1Division of Pediatric Pulmonology and Neonatology, Medizinische Hochschule Hannover, Hannover, Germany. 2Division of Allergy and Pulmonology, and ${ }^{3}$ Division of Hematology and Oncology, Department of Pediatrics, Martin Luther University Halle-Wittenberg, Halle, Germany.

${ }^{4}$ Fraunhofer Institute of Toxicology and Experimental Medicine, Hannover, Germany. ${ }^{5}$ Department of Pediatrics and Children's Hospital Medical Center Technische Universität München, Munich, Germany. ${ }^{6}$ Department of Surgery and Emory Vaccine Center, Emory University, Atlanta, Georgia, USA.
\end{abstract}

\begin{abstract}
The prevalence of asthma continues to increase. Asthma is caused by a Th2 cell-driven immune response. Its optimal treatment remains a challenge, and a sufficient immunotherapeutic approach to treating asthma has yet to be found. Using a murine asthma model, we show that a single injection of an anti-CD137 (4-1BB) $\mathrm{mAb}$ prevents the development of airway hyperreactivity, eosinophilic airway inflammation, excessive mucus production, and elevated IgE during the observation period of 7 weeks. Most importantly, even established disease is completely reversed by anti-CD137 mAb administration. The protection is associated with markedly reduced Th2 cytokine production and increased secretion of the Th1 cytokine IFN- $\gamma$. While B lymphocytes are partly depleted, the number of $\mathrm{CD8}^{+} \mathrm{T}$ cells is increased. Blockade of IFN- $\gamma$ and depletion of $\mathrm{CD8}^{+} \mathrm{T}$ cells during treatment with anti-CD137 mAb reduces in part but does not abrogate the protective effect of CD137 $\mathrm{mAb}$. In contrast, $\mathrm{CD} 137 \mathrm{mAb}-$ mediated $\mathrm{CD}^{+} \mathrm{T}$ cell anergy is critical for the observed effects, since transfer of CD4 ${ }^{+} \mathrm{T}$ cells from $\mathrm{CD} 137 \mathrm{mAb}$-treated mice conveyed protection. These data demonstrate, for the first time to our knowledge, the capacity of anti-CD137 mAb to ameliorate allergic asthma, and they indicate CD137 as a possible target for therapeutic intervention in this disease.
\end{abstract}

\section{Introduction}

Asthma, which has increased substantially in prevalence in the last 2 decades, is characterized by airway hyperreactivity (AHR) to a variety of specific and nonspecific stimuli; chronic airway inflammation with pulmonary eosinophilia; mucus hypersecretion; and increased serum IgE levels (1). Asthma is believed to be a result of an inappropriate Th2 cell-mediated immune response to common aeroallergens in genetically susceptible individuals. Although the immunological mechanisms that induce asthma or allergies are relatively well characterized, the specific mechanisms that downmodulate Th2 cell-driven allergic inflammatory responses in the lung are poorly understood. Current therapies for asthma, such as inhaled corticosteroids and $\beta_{2}$-agonists, relieve symptoms but do not reverse the progression of or cure this disease, and a sufficient immunotherapeutic approach to treating asthma has yet to be found. So far, it is not clear whether there are certain molecular interactions that could be targeted to either suppress ongoing lung inflammation or prevent the recurrence of asthmatic symptoms when airborne allergens are repeatedly encountered.

One causal strategy to control asthma is to directly modify $\mathrm{T}$ cell activation by targeting costimulatory interactions that are involved in this process (2). Optimal $\mathrm{T}$ cell activation requires at least 2 signals, provided by recognition of peptide-MHC proteins by the TCR, and by interaction of T cell costimulatory receptors with their ligands on APCs. The ligation of the CD28 molecule on T cells to B7-1 or B7-2 on APCs is essential for naive T cell survival and differentiation. Memory $\mathrm{T}$ cell responses are often CD28

Nonstandard abbreviations used: AHR, airway hyperreactivity; BAL, bronchoalveolar lavage; MSB, martius scarlet blue.

Conflict of interest: The authors have declared that no conflict of interest exists. Citation for this article: J. Clin. Invest. 116:1025-1036 (2006). doi:10.1172/JCI23792. costimulation independent, and many other molecules positively or negatively influence $T$ cell activation and differentiation (3-5).

One of these other costimulatory molecules is CD137 (4-1BB), a member of the TNF receptor family (6). It is expressed on activated T cells, NK cells, and DCs, while its ligand, CD137L, has been detected on mature DCs, activated macrophages, and activated B cells (7). It has been shown that CD137 can costimulate T cell activation and proliferation $(8,9)$, enhances the survival of activated $\mathrm{T}$ cells (10), and suppresses CD $4^{+} \mathrm{T}$ cell help during $\mathrm{T}$ cell-dependent humoral immune responses (11). Previous animal studies have shown that short-term administration of agonistic mAbs against the costimulatory molecule CD137 induces rejection of established tumors $(12,13)$, enhances the $\mathrm{CD}^{+} \mathrm{T}$ cell responses to viruses (14), blocks autoimmune disease progression $(15,16)$, and suppresses rheumatoid arthritis $(17,18)$. So far it seemed that costimulation through CD137 preferentially induces Th1 responses and $\mathrm{CD}^{+} \mathrm{T}$ cell proliferation $(16,19,20)$. However, recently it has been shown in a model of LPS-induced shock syndromes that CD137-deficient mice do not generate a rapid IL-4 response after systemic $\mathrm{T}$ cell activation, nor effective antigen-specific Th2 responses (21). These data support a role for CD137 also in IL-4dependent Th2 responses such as allergic diseases. However, the role of CD137 in allergic diseases is mostly unknown. There is just 1 human study demonstrating that functional CD137 receptors are expressed by eosinophils from patients with IgE-mediated allergic responses but not by eosinophils from patients with nonIgE-mediated eosinophilic disorders (22).

In the present study, we investigated the role of CD137 in a murine model of allergic asthma and found that CD137 is critical in determining the outcome of this Th2 cell-mediated disease. A single injection of an agonistic anti-CD137 mAb was able to inhibit AHR, eosinophilic airway inflammation, Th2 cytokine production, 


\section{Prevention}

Anti-CD137 mAb

Reversal I

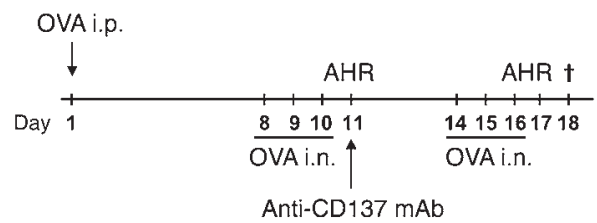

Reversal II

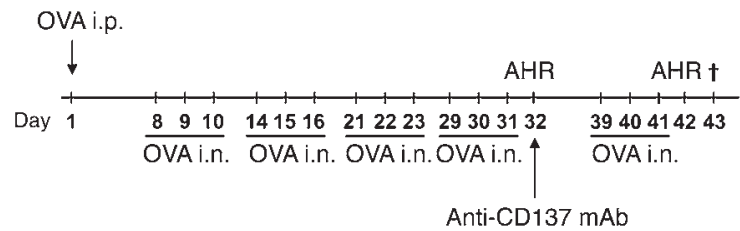

and specific IgE synthesis for the complete observation period of almost 7 weeks. Most important, CD137 signaling was essential not only during priming but also in the effector cell response of this disease, since anti-CD137 mAb could reverse already established asthma when applied 11 days or even as late as 32 days after the first immunization. Signs of airway remodeling such as increased subepithelial deposition of ECM proteins and the amount of total lung collagen, seen 42 days after the first OVA immunization, were clearly decreased by anti-CD $137 \mathrm{mAb}$ therapy. The observed protective effects of anti-CD137 mAb depended partly on $\mathrm{CD}^{+} \mathrm{T}$ cells and IFN- $\gamma$ but could also be traced back to $C D 4^{+} \mathrm{T}$ cell anergy. The findings reported here show that CD137 signaling plays a central role in Th2 cell-mediated immune responses and indicate that strategies aimed at stimulation of CD137 may represent a therapeutic target during allergic inflammatory responses and other disorders characterized by inappropriate $\mathrm{T}$ cell activation.

\section{Results}

Agonistic anti-CD137 $m A b$ prevents the development of $A H R$ and airway inflammation in OVA-immunized BALB/c mice. To investigate the role of the costimulatory molecule CD137 in the Th2 cell-mediated immune response of allergic asthma, we tested an agonistic antiCD137 mAb in our well-established murine asthma model $(23,24)$. In this model, an asthma-like phenotype with AHR, eosinophilic airway inflammation, mucus hypersecretion, and high IgE levels is induced by sensitization of mice to OVA by systemic and intrapulmonary applications of this model allergen (Figure 1). Injection of anti-CD137 mAb 1 day before the beginning of OVA priming completely prevented the development of methacholine-induced AHR in $\mathrm{BALB} / \mathrm{c}$ mice as measured in a whole-body plethysmograph for mice 1 day after the last intranasal OVA challenge (day 17, Figure 2A). Even 45 days after a single anti-CD137 mAb injection, AHR was still completely inhibited as compared with OVA-immunized control mice that had received an isotype-matched antibody instead of anti-CD137 mAb (Figure 2A).

Agonistic anti-CD $137 \mathrm{mAb}$ was also very effective in inhibiting the development of eosinophilic airway inflammation in OVA-immu-

\section{Figure 1}

Immunization and antibody treatments. Prevention protocol: Mice were immunized with OVA i.p. on days 1 and 14, followed by intranasal (i.n.) OVA challenges on days 14-16, 28-30, and 42-44. Anti-CD137 mAbs were injected i.p. 1 day before the first OVA immunization. AHR was measured on days 17 and 45, and mice were sacrificed on day 18 (acute phase) or 46 (chronic phase). Reversal protocol I: Mice were immunized with OVA i.p. on day 1 , followed by intranasal OVA challenges on days 8-10. To confirm the induction of AHR by OVA sensitization, AHR was measured the following day. Anti-CD137 mAb or control mAb was injected i.p. 12 hours after AHR measurement on day 11. Intranasal OVA challenge was repeated on days 15-17, and AHR was measured on day 18. Mice were sacrificed the following day. Reversal protocol II: Mice were immunized with OVA i.p. on day 1 , followed by intranasal OVA challenges on days 8-10, 14-16, 21-23, and 29-31. To confirm the induction of AHR by OVA sensitization, AHR was measured the following day. Anti-CD137 mAb or control mAb was injected i.p. 12 hours after AHR measurement on day 32. Intranasal OVA challenge was repeated on days 39-41, and AHR was measured on day 42. Mice were sacrificed the following day (indicated by cross). nized BALB/c mice. Injection of anti-CD137 mAb before OVA priming reduced the total cell number as well as the number of eosinophils in the bronchoalveolar lavage (BAL) fluid almost 6-fold as compared with the OVA-immunized control group when BAL was performed on day 18 (Figure 2B). Similar to the observations made with AHR, the antiinflammatory effect of a single anti-CD137 mAb injection lasted for more than 6 weeks as demonstrated by analysis of BAL fluid 46 days after anti-CD137 mAb injection (Figure 2B).

Accordingly, histological examination of H\&E-stained lung sections isolated from OVA-immunized mice 46 days after injection of anti-CD137 mAb or control mAb revealed significantly decreased airway inflammation in the anti-CD137 mAb-treated group compared with the control group (Figure 2C). Inhibition of airway inflammation by anti-CD137 mAb could be verified by an objective, investigator-independent computer program based on morphometric image analysis of lung sections from at least 9 animals per group (Figure 2D).

Not only airway inflammation but also mucus production were impressively reduced by anti-CD $137 \mathrm{mAb}$ injection as revealed by histological analysis of PAS-stained lung sections 46 days after anti-CD137 mAb injection (Figure 2E). As for lung inflammation, this effect could be verified by our investigator-independent computer-based analysis of the PAS-stained lung sections (Figure 2F).

To investigate the effect of anti-CD137 mAb on cytokine production in OVA-immunized BALB/c mice, spleen cells were isolated 17 and 46 days after antibody injection and restimulated in vitro with OVA for 3 days. Analysis of cytokine levels in cell culture supernatants showed that anti-CD $137 \mathrm{mAb}$ significantly decreased the production of the Th2 cytokines IL-4, IL-13, IL-5, and IL-10 and at the same time significantly increased IFN- $\gamma$ production (Figure $2 \mathrm{G}$ ). Although these effects diminished over time, they were still significant 46 days after anti-CD137 mAb injection. In parallel, ex vivo proliferation of OVA-stimulated splenocytes isolated from these animals was almost completely inhibited at both measurement points (Figure $2 \mathrm{H}$ ).

In parallel, serum levels of OVA-specific $\mathrm{IgE}$ and $\mathrm{IgG}_{1}$ were entirely inhibited in the anti-CD137 mAb-treated group 17 and 46 days 

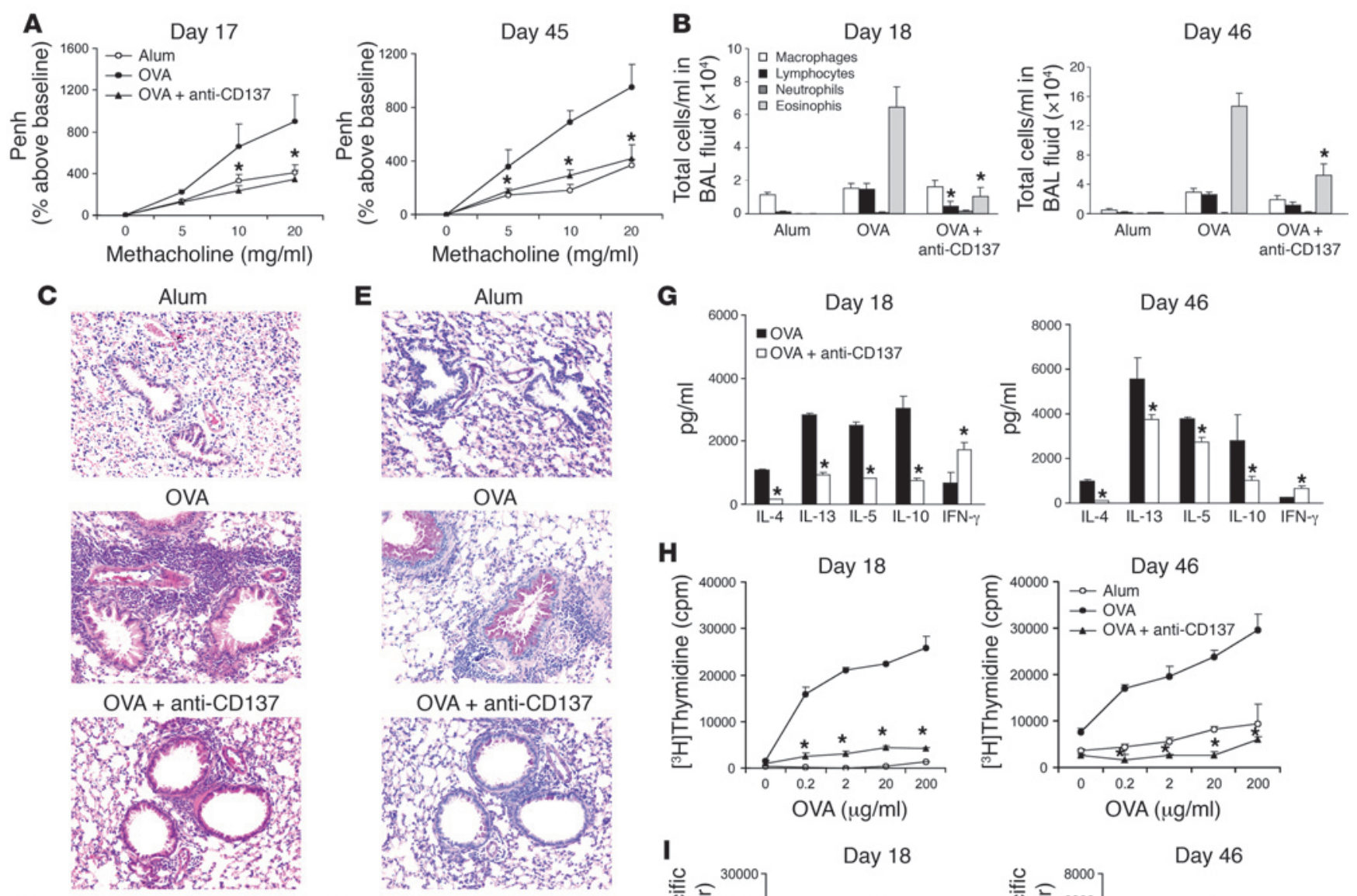

$\mathbf{E}$

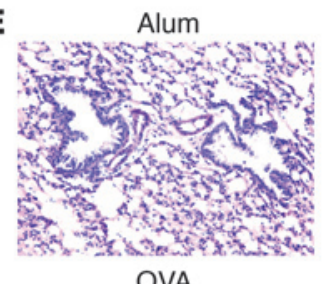

G

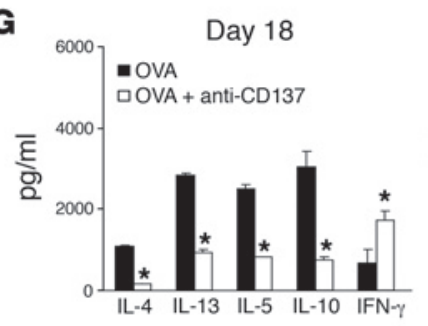

Day 46


Figure 2

Agonistic anti-CD137 mAb prevents AHR and eosinophilic airway inflammation in OVA-immunized BALB/c mice. (A) Methacholine-induced AHR was measured 17 and 45 days after antibody injection. At both time points, anti-CD137 mAb completely inhibited AHR in OVA-immunized mice (measured by enhanced pause [Penh]). (B) The increased cell number in the BAL fluid of OVA-immunized mice was almost completely abrogated by anti-CD137 mAb at both observation points. (C) Lung tissues from BALB/c mice sacrificed on day 46 (H\&E; magnification, $\times 100)$ revealed dense peribronchiolar mononuclear cell infiltrates consisting mainly of lymphocytes and eosinophils in the OVA-immunized group. Inflammation was strongly reduced by anti-CD137 mAb. (D) Computer-based quantification of lung inflammation clearly demonstrated the significant antiinflammatory effect of anti-CD137 mAb. (E) PAS-stained lung sections (magnification, $\times 100$ ) revealed mucus hypersecretion in OVA-immunized mice compared with controls, which was almost abrogated by anti-CD137 mAb. (F) Computer-based quantification of mucus production clearly verified inhibition of mucus production by anti-CD137 mAb. (G) Anti-CD137 mAb inhibited Th2 and induced Th1 cytokine production. This effect was still significant on day 46. (H) Anti-CD137 mAb almost completely inhibited proliferation of spleen cells of OVA-immunized BALB/c mice. (I) Anti-CD137 mAb significantly reduced OVA-specific $\operatorname{lgE}$ and $\lg \mathrm{G}_{1}$ serum levels on days 18 and 46 in OVA-immunized mice. ${ }^{*} P<0.05$, OVA plus anti-CD137 mAb versus OVA plus control antibody by Student's $t$ test. (A-F) $n \geq 9$ animals per group and data point; data are expressed as mean \pm SEM from 3 independent experiments. $(\mathbf{G}-\mathbf{I}) n \geq 4$ animals per group; here representative results from 1 of 3 experiments are shown.

after anti-CD137 mAb injection (Figure 2I), while the effects on OVA-specific $\operatorname{IgG}_{2 \mathrm{a}}$ were not consistent (data not shown).

Anti-CD137 mAb treatment led to splenomegaly 17 days after antibody injection that could not be observed anymore 46 days after the antibody had been applied. The transient increase in size and weight (OVA: $0.162 \pm 0.016 \mathrm{~g}$; OVA plus anti-CD137 mAb: $0.325 \pm 0.065 \mathrm{~g}$ ) of the spleens could not be explained by differences in total cell numbers of the spleens (OVA: $8.25 \times 10^{6} \pm 1.28 \times 10^{6}$ 
A



B

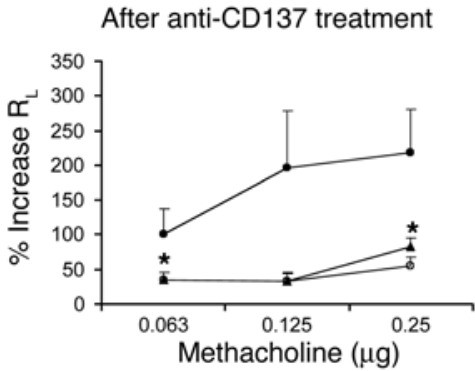

$\mathbf{E}$

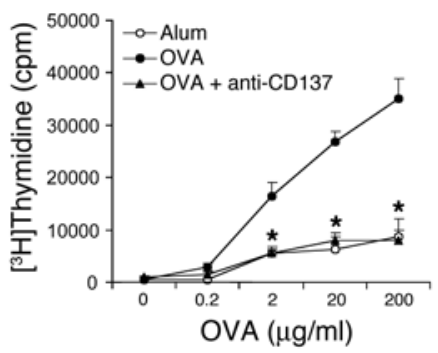





$\mathbf{F}$



C

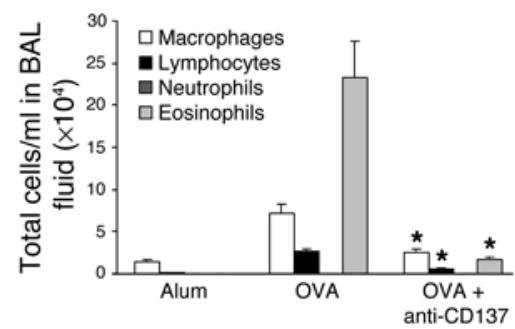

D


Figure 3

Therapeutic effect of anti-CD137 mAb on the established asthma phenotype. BALB/c mice were immunized with OVA on day 1 and challenged with OVA intranasally on days 8-10. After treatment with anti-CD137 mAb or control mAb on day 11, mice were challenged again with OVA on days 15-17. (A) OVA immunization resulted in methacholine-induced AHR as measured 1 day after the last intranasal OVA challenge (day 10). Injection of anti-CD137 mAb 12 hours after the first AHR measurement (day 11) completely inhibited this already established AHR as demonstrated 7 days later. (B) After the last challenge with OVA (day 17), AHR was assessed invasively on day 18, and results are presented as lung resistance $\left(R_{L}\right)$ and dynamic compliance (Cdyn). (C) Mice were sacrificed on day 18, and BAL was performed. Anti-CD137 mAb almost completely abrogated the total cell number in the BAL fluid of OVA-immunized BALB/c mice. (D) Anti-CD137 mAb converted an established Th2 to a Th1 cytokine response in OVA-immunized BALB/c mice. (E) Anti-CD137 mAb inhibited proliferation of spleen cells from OVA-immunized BALB/c mice. (F) Anti-CD137 mAb reduced OVA-specific lgE and IgG 1 serum levels in OVA-immunized BALB/c mice. ${ }^{*} P<0.05$, OVA plus anti-CD137 mAb versus OVA plus control antibody by Student's $t$ test. (A and $\mathbf{B}) n \geq 9$ animals per group and data point; data are expressed as mean \pm SEM from 3 independent experiments. (C-E) $n \geq 4$ animals for each group; here representative results from 1 of 3 experiments are shown.

cells/ml; OVA plus anti-CD137 mAb: $8.92 \times 10^{6} \pm 2.29 \times 10^{6}$ cells/ $\mathrm{ml} ; n=9$ ) but may have been partly due to an increase in connective tissue, as revealed by histological analysis of the spleens. Fortysix days after anti-CD137 mAb injection, appearance, weight, and histology of the spleen were back to normal (data not shown). The observed transient splenomegaly after anti-CD137 mAb treatment has also been seen in other studies $(16,25)$.

In summary, stimulation of the CD137 costimulatory pathway by an agonistic mAb prevented the development of AHR, eosinophilic airway inflammation, and mucus production in OVA-immunized BALB/c mice. These effects were accompanied by inhibition of Th2 cytokine production, stimulation of Th1 cytokine production, and inhibition of IgE serum levels, as well as inhibition of splenocyte proliferation. All effects were observed 17 as well as 46 days after a single injection of anti-CD137 mAb.

Agonistic anti-CD137 $m A b$ reverses an established asthma phenotype in OVA-immunized $B A L B / c$ mice. To test the therapeutic potential of anti-CD137 mAb, we first immunized BALB/c mice with OVA and then injected the agonistic anti-CD137 mAb after the asthma phenotype was already fully established. Treatment of OVA-immunized mice with anti-CD137 mAb abolished AHR and eosinophilic airway inflammation (Figure 3, A and C), demonstrating that anti-CD137 mAb treatment is capable of reversing very effectively these 2 key features of allergic asthma. We confirmed the inhibitory effect of anti-CD137 mAb on AHR in orotracheally intubated, spontaneously breathing mice by assessing AHR using direct invasive assays for dynamic compliance and lung resistance in the antiCD137 mAb-treated animals (Figure 3B).

In the therapy model, as in the prevention model, the inhibitory effect of anti-CD137 mAb on AHR and inflammation was associated with significant inhibition of the Th2 cytokines IL-4, IL-13, IL-5, and IL-10 and induction of the Th1 cytokine IFN- $\gamma$, measured in cell culture supernatants of OVA-stimulated spleen (Figure 3D) and lung cells (data not shown). Moreover, injection 
Table 1

Effects of anti-CD137 mAb on lymphocyte populations

\begin{tabular}{llll} 
& & \multicolumn{3}{c}{ Total cell number $(\times \mathbf{1 0 7})$} \\
Lymphocytes & \multicolumn{1}{c}{ Alum } & OVA + control Ab & OVA + anti-CD137 \\
CD8 & $0.86 \pm 0.001(10.8 \%)$ & $0.95 \pm 0.01(11.5 \%)$ & $1.71 \pm 0.02^{A}(19.4 \%)$ \\
CD19+ & $3.18 \pm 0.06(39.7 \%)$ & $3.85 \pm 0.02(46.5 \%)$ & $2.37 \pm 0.46^{A}(26.6 \%)$ \\
CD4+ & $1.61 \pm 0.13(20.0 \%)$ & $1.67 \pm 0.22(20.3 \%)$ & $2.07 \pm 0.57(23.2 \%)$ \\
CD4 $4^{+}$CD25+ & $0.56 \pm 0.13(7 \%)$ & $0.65 \pm 0.09(7.9 \%)$ & $0.50 \pm 0.07(5.7 \%)$ \\
\hline
\end{tabular}

BALB/c mice were immunized with OVA on day 1 and challenged with OVA intranasally on days 8-10. After treatment with anti-CD137 mAb or control mAb on day 11, mice were challenged again with OVA on days 15-17. On day 18 , mice were sacrificed, and spleen cells were stained with specific mAbs as described in Methods for FACS analysis. Anti-CD137 $\mathrm{mAb}$ increased the number of $\mathrm{CD} 8^{+} \mathrm{T}$ cells, had no influence on the number of $\mathrm{CD} 4^{+}$and CD4 ${ }^{+} \mathrm{CD} 25^{+} \mathrm{T}$ cells, and depleted CD19+ $\mathrm{B}$ cells of splenocytes in OVA-immunized BALB/C mice. ${ }^{A} P<0.05$, OVA plus anti-CD137 mAb versus OVA plus control antibody by Student's $t$ test. Data are expressed as mean \pm SEM from 3 independent experiments; $n \geq 4$ animals per group and data point.

of anti-CD137 mAb into OVA-immunized mice almost completely inhibited the ex vivo proliferation of OVA-stimulated splenocytes isolated from these animals (Figure 3E).

FACS analysis of the different cell types of BALB $/ \mathrm{c}$ mice revealed a nearly 2 -fold increase in the percentage ( $11.5 \%$ to $19.4 \%$, OVA to OVA plus anti-CD137 mAb) and total number $\left(0.95 \times 10^{7} \pm 0.01 \times 10^{7}\right.$ to $1.7 \times 10^{7} \pm 0.02 \times 10^{7}$ ) of $\mathrm{CD}^{+} \mathrm{T}$ cells (Table 1 ) in the antiCD137 mAb-treated group. However, we observed no significant changes in the percentage and total number of $\mathrm{CD}^{+} \mathrm{T}$ cells and $\mathrm{CD} 4{ }^{+} \mathrm{CD} 25^{+} \mathrm{T}$ cells (Table 1 ).

The anti-CD137 mAb-mediated decrease in B cells $(46.5 \%$ to $26.6 \%$, and total cell number $3.85 \times 10^{7} \pm 0.023 \times 10^{7}$ to $2.37 \times 10^{7}$ $\pm 0.46 \times 10^{7}$, OVA to OVA plus anti-CD137 $\mathrm{mAb}$; Table 1 ) was associated with a significant inhibition of OVA-specific $\mathrm{IgE}$ and $\mathrm{IgG}_{1}$ serum levels (Figure 3F).

Very impressively, the inhibitory effect of anti-CD137 mAb on the asthma phenotype was virtually the same when anti-CD137 $\mathrm{mAb}$ was injected more than 4 weeks after the first immunization with OVA (Figure 1, reversal II, and Figure 4, A-E). This was true for all measured parameters, including AHR, lung inflammation, and cytokine and Ig production, demonstrating that anti-CD137 $\mathrm{mAb}$ really reverses the disease. Also, inhibition of Th2 cytokines and induction of Th1 cytokine was comparable in the supernatants of lung and spleen cells when the antibody was applied on day 32 after the first immunization instead of day 11 (Figure 4, D and E).

Furthermore, in this long-lasting asthma model, we investigated the effect of anti-CD137 mAb therapy on airway remodeling. Increased subepithelial deposition of ECM proteins, specifically collagen, is a prominent feature of airway remodeling. We examined matrix deposition (collagen and fibrin) in lung sections stained with martius scarlet blue (MSB). This staining has been shown to be specific for collagen and old fibrin $(26,27)$. Control mice that had not been immunized to OVA showed a thin uniform layer of matrix in peribronchiolar subepithelial regions, whereas prolonged challenge with OVA significantly increased matrix deposition in the subepithelial layer of the bronchioles. Dense fibrils were seen in the subepithelial and submucosal regions and between the inflammatory cells. Anti-CD137 mAb treatment clearly reduced ECM deposition (Figure 5A). Quantification by computer-based image analysis of MSB-stained lung sections confirmed these results (Figure 5B). The therapeutic effect of anti-CD137 mAb on airway remodeling demonstrated by lung histology was also shown by biochemical measurement of total lung collagen. Application of anti-CD137 mAb significantly reduced the amount of total lung collagen in anti-CD137 mAb-treated mice compared with mice that had received control antibody instead (Figure 5C). In summary, our data clearly demonstrate a therapeutic effect of anti-CD137 $\mathrm{mAb}$ on airway remodeling in our murine asthma model.

Anti-CD137 mAb-driven protective effects on airway inflammation and $A H R$ depend partly on $C D 8^{+}$ $T$ cells and IFN- $\gamma$. Previous studies have shown a critical role for both $\mathrm{CD}^{+} \mathrm{T}$ cells and IFN- $\gamma$ in mediating the effects of $\operatorname{CD} 137(15,17)$. In our model, the number of $\mathrm{CD}^{+} \mathrm{T}$ cells and the secretion of IFN- $\gamma$ were increased by antiCD137 mAb, supporting a possible role of these 2 parameters. To investigate the mechanisms underlying the therapeutic effect of anti-CD137 mAb in the murine asthma model, we depleted $\mathrm{CD}^{+} \mathrm{T}$ cells and blocked IFN- $\gamma$ by using specific anti$\mathrm{CD} 8 \mathrm{mAb}$ or anti-IFN- $\gamma \mathrm{mAb}$. Injection of anti-CD8 $\mathrm{mAb}$ resulted in $99 \%$ depletion of $\mathrm{CD}^{+}$cells compared with those in control animals (data not shown). Depletion of $\mathrm{CD}^{+} \mathrm{T}$ cells and blockade of IFN- $\gamma$ had similar effects: both significantly reduced the therapeutic effect of anti-CD137 mAb treatment on AHR (Figure 6, $\mathrm{A}$ and $\mathrm{B}$ ) and eosinophilic inflammation (Figure 6, C and D) in OVA-sensitized BALB/c mice. While the effect of $\mathrm{CD}^{+} \mathrm{T}$ cell depletion and IFN- $\gamma$ blocking on AHR was comparable, the effect of anti-IFN- $\gamma$ on the inflammatory response was higher than that of $\mathrm{CD}^{+} \mathrm{T}$ cell depletion (Figure $6, \mathrm{C}$ and $\mathrm{D}$ ).

AHR and airway inflammation of OVA-immunized mice that received only anti-CD8 mAb or anti-IFN- $\gamma$ mAb but not CD137 $\mathrm{mAb}$ were not significantly changed, which demonstrates that the observed effects of IFN- $\gamma$ inhibition and $\mathrm{CD}^{+} \mathrm{T}$ cell depletion were indeed specific for CD137 (Figure 6, A-D).

Since anti-CD137 $\mathrm{mAb}$ treatment increases IFN- $\gamma$ production of $\mathrm{CD}^{+} \mathrm{T}$ cells as seen by intracellular FACS staining, the observed effect of $\mathrm{CD}^{+} \mathrm{T}$ cell depletion might have been due to IFN- $\gamma$ produced by these cells. In contrast to the observed effects on AHR and inflammation, $\mathrm{CD}^{+} \mathrm{T}$ cell depletion and blocking of IFN- $\gamma$ did not alter the anti-CD137 mAb-mediated inhibition of Th2 cytokine production (Figure 6, E and F) and Ig synthesis (data not shown). This was surprising, since, on the one hand, IFN- $\gamma$ inhibits Th2 cytokine production in many systems, and, on the other hand, the number of $\mathrm{CD} 19^{+} \mathrm{B}$ cells was normalized after $\mathrm{CD} 8^{+} \mathrm{T}$ cell depletion in anti-CD137 mAb-treated mice as opposed to antiCD137 mAb-treated but not CD8 ${ }^{+} \mathrm{T}$ cell-depleted mice (data not shown). Our data demonstrate that inhibition of AHR and eosinophilic airway inflammation by anti-CD137 mAb is mediated partly, but nowhere near completely, by $\mathrm{CD} 8^{+} \mathrm{T}$ cells and IFN- $\gamma$.

Anti-CD137 $m A$ Ab induces $C D 4^{+} T$ cell anergy. Since the anti-CD137 mAb-mediated effects in the Th2 cell-driven murine asthma model depended only partly on $\mathrm{CD}^{+} \mathrm{T}$ cells and IFN- $\gamma$, we further investigated how the protective effect of CD137 mAb is mediated by analyzing the role of $\mathrm{CD}^{+} \mathrm{T}$ cells in the anti-CD137 $\mathrm{mAb}-$ mediated protective effects. $\mathrm{CD} 4^{+} \mathrm{T}$ cells play the crucial role in the asthma pathogenesis, as demonstrated by a large series of animal models showing that the initiation of the asthmatic reaction 
A


D



$\mathbf{E}$

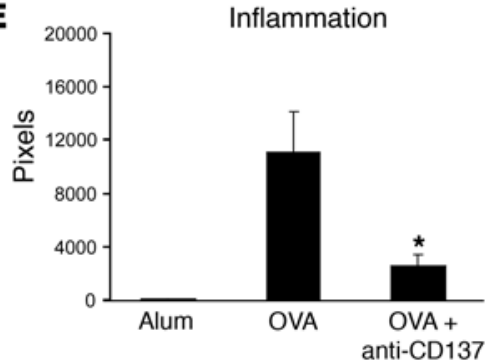





\section{Figure 4}

Therapeutic effect of anti-CD137 mAb in a chronic asthma model. BALB/c mice were immunized with OVA on day 1 and challenged with OVA several times intranasally during the following 31 days. Lung function was measured on day 32. Anti-CD137 mAb was injected the same day, followed by further intranasal challenges with OVA (days 39-41). (A) OVA immunization resulted in methacholine-induced AHR as measured 1 day after the last intranasal OVA challenge (day 32). Injection of anti-CD137 mAb 12 hours after the first AHR measurement completely inhibited this already established AHR as demonstrated 10 days later. (B) Mice were sacrificed on day 43, and BAL was performed. Anti-CD137 $\mathrm{mAb}$ almost completely abrogated the total cell number in the BAL fluid of OVA-immunized BALB/c mice. (C) Anti-CD137 mAb reduced OVA-specific IgE serum levels in OVA-immunized BALB/c mice. (D) Anti-CD137 mAb converted an established Th2 to a Th1 cytokine response in culture supernatants of splenocytes and lung cells in OVA-immunized BALB/c mice. (E) Quantification of lung inflammation and mucus production by a computer-based image-analyzing program clearly demonstrated the inhibitory effect of anti-CD137 mAb. ${ }^{*} P<0.05$, OVA plus anti-CD137 mAb versus OVA plus control antibody by Student's $t$ test. (A, B, and $\mathbf{E}) n \geq 8$ animals per group and data point; data are expressed as mean \pm SEM from 2 independent experiments. (C and D) $n \geq 4$ animals for each group; here representative results from 1 of 2 experiments are shown.

is dependent on $\mathrm{CD}^{+} \mathrm{T}$ cells $(28,29)$, with the strongest evidence provided by experiments in which passive transfer of Th2 cell clones is able to induce AHR and inflammation in immunodeficient and immunocompetent mice $(23,30,31)$.

To investigate the role of $\mathrm{CD}^{+} \mathrm{T}$ cells in the CD137-mediated effects in our model, we treated OVA-immunized BALB/c mice with anti-CD137 $\mathrm{mAb}$ or control $\mathrm{mAb}$. $\mathrm{CD}^{+} \mathrm{T}$ cells were isolated from these animals and transferred into SCID mice that received OVA intranasally 1 day before and 2 days after cell transfer. While transfer of $\mathrm{CD}^{+} \mathrm{T}$ cells from OVA-immunized mice that had received the control $\mathrm{mAb}$ significantly induced $\mathrm{AHR}$ in response to methacholine in the $T$ cell recipients, this effect was almost abrogated when $\mathrm{CD}^{+} \mathrm{T}$ cells from OVA-immunized and antiCD137 mAb-treated BALB/c mice were transferred (Figure 7A). While $\mathrm{CD}^{+} \mathrm{T}$ cells derived from OVA-immunized BALB/c mice strongly proliferated in response to OVA, there was no proliferation of $\mathrm{CD}^{+}{ }^{+} \mathrm{T}$ cells derived from anti-CD137 mAb-treated OVAimmunized animals (Figure $7 \mathrm{~B}$ ). $\mathrm{CD}^{+} \mathrm{T}$ cell death was excluded by viability assay with trypan blue (data not shown). In the pres- ence of IL-2, $\mathrm{CD}^{+} \mathrm{T}$ cells from anti-CD137 mAb-treated OVAimmunized mice proliferated again (Figure 7B). Moreover, in the presence of IL-2, reduced Th2 cytokine production from $\mathrm{CD}_{4}^{+} \mathrm{T}$ cells derived from anti-CD137 mAb-treated OVA-immunized mice was almost back to normal (Figure $7 \mathrm{C}$ ). Coculture of unresponsive $\mathrm{CD}^{+} \mathrm{T}$ cells with $\mathrm{CD} 4^{+}$effector cells did not result in inhibition of effector cells, as one would expect from $T$ regulatory cells (data not shown). These findings support the induction of classical $\mathrm{T}$ cell anergy by $\mathrm{CD} 137 \mathrm{mAb}$ in the murine asthma model.

Our data do not show a role for $\mathrm{CD} 4^{+} \mathrm{CD} 25^{+} \mathrm{T}$ cells or IL-10 and TGF- $\beta$ in mediating $\mathrm{CD}^{+} \mathrm{T}$ cell anergy, since we did not see any effect on the number of $\mathrm{CD} 4^{+} \mathrm{CD} 25^{+} \mathrm{T}$ cells (Table 1 ) or an increase of IL-10 or TGF- $\beta$ after anti-CD137 mAb injection. In contrast, IL-10 was even decreased (Figures $2 \mathrm{G}$ and $3 \mathrm{D}$ ), and TGF- $\beta$ was not significantly changed $(253 \pm 37$ to $198 \pm 16 \mathrm{pg} / \mathrm{ml}$, OVA to OVA plus anti-CD137).

In summary, our data demonstrate the crucial role of anti$\mathrm{CD} 137 \mathrm{mAb}-$ induced $\mathrm{CD} 4^{+} \mathrm{T}$ cell anergy in the protective effects of anti-CD137 $\mathrm{mAb}$ in the murine asthma model. 
A



OVA

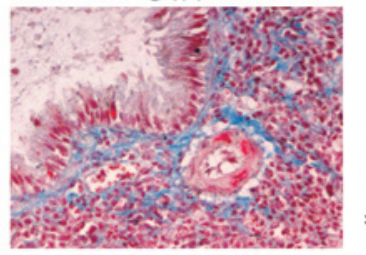

OVA + anti-CD137
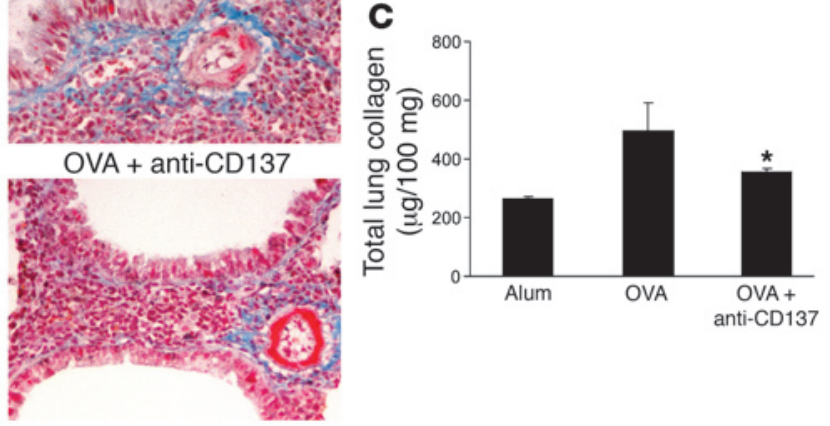

\section{Figure 5}

Therapeutic effect of anti-CD137 mAb on airway remodeling. BALB/c mice were immunized with OVA on day 1 and challenged with OVA intranasally several times according to reversal protocol II (Figure 1), described in Methods. After application of anti-CD137 mAb or control $\mathrm{mAb}$ on day 32 , mice were challenged again with OVA on days 39-41. On day 43, mice were sacrificed. (A) MSB-stained lung tissues (magnification, $\times 400$ ) from BALB/c mice revealed increased peribronchiolar ECM deposition, which was reduced by anti-CD137 mAb. (B) For quantification of ECM deposition, digital photographs of 4 bronchioles per tissue section were taken and analyzed with a computerbased image-analyzing program, demonstrating the protective effect of anti-CD137 mAb. (C) Total lung collagen was increased in OVAimmunized mice compared with control animals. This effect was partly abrogated $(62 \%)$ by anti-CD137 mAb application. ${ }^{*} P<0.05$, OVA plus anti-CD137 mAb versus OVA plus control antibody by Student's $t$ test. $n \geq 8$ animals per group; data are expressed as mean \pm SEM from 2 independent experiments.

\section{Discussion}

Previous animal studies have shown that short-term administration of an agonistic antibody reactive with CD137, a costimulatory molecule of the TNF receptor family, induces rejection of established tumors $(12,13)$, enhances $\mathrm{CD}^{+} \mathrm{T}$ cell responses to viruses (14), blocks autoimmune disease progression $(15,16)$, and suppresses rheumatoid arthritis (17). In the present study, we show in our previously well-characterized Th2 cell-mediated murine asthma model $(23,33,34)$ that signaling via CD137 controls not only CD8 ${ }^{+} \mathrm{T}$ cell- and Th1-mediated immune responses but also the Th2 cell-mediated disease allergic asthma. A single injection of anti-CD137 mAb before OVA priming of BALB/c mice prevented the development of AHR, eosinophilic airway inflammation, excessive mucus production, and elevated serum IgE levels during the complete observation period of almost 7 weeks. Most important, agonistic anti-CD137 mAb was comparably effective in reversing already established AHR and eosinophilic airway inflammation. Even when the anti-CD137 mAb was given late after the first OVA priming, when there is no new Th2 generation and no further recruitment of OVA-specific Th2 cells and when the airways are inflamed, the asthma phenotype was completed reversed by a single anti-CD137 mAb injection. The prolonged allergen challenge in mice leads to the development of airway remodeling, an important feature of chronic asthma. We found that anti-CD137 $\mathrm{mAb}$ application clearly reduced increased collagen matrix deposition. This observation together with the long-lasting protective action of anti-CD137 mAb suggests that immunotherapy with anti-CD137 mAb might be effective in patients with asthma, who by definition have ongoing AHR and airway inflammation.

The inhibitory effect of anti-CD137 mAb on AHR and inflammation was associated with significant inhibition of the Th2 cytokines IL-4, IL-5, IL-10, and IL-13, which all play a crucial role in the development of AHR and inflammation in allergic asthma and are found in high concentrations at sites of allergic inflammation in humans $(1,34,35)$. In contrast, as shown before in vitro (19) as well as in vivo in a murine model of autoimmune disease

(15) and rheumatoid arthritis (17), synthesis of the Th1 cytokine IFN- $\gamma$ was strongly induced.

A protective role of IFN- $\gamma$ has been shown in murine models of asthma in which mucosal IFN- $\gamma$ gene transfer and nebulized IFN- $\gamma$ application inhibited eosinophilic inflammation $(36,37)$. Indirect evidence for a protective role of IFN- $\gamma$ has also been demonstrated in a human study, where allergen immunotherapy increased IFN- $\gamma$ production by circulating $\mathrm{T}$ lymphocytes in patients with clinical benefit (38). Because the Th1 cytokine IFN- $\gamma$ cross-regulates Th2 cells in some systems (39), IFN- $\gamma$ is thought to be critically involved in downmodulating Th 2 cell-driven AHR and asthma. Blocking of IFN- $\gamma$ in our system significantly reduced the protective effect of anti-CD137 mAb on AHR and airway inflammation. However, it did not increase the low Th2 cytokine levels or OVA-specific IgE and $\mathrm{IgG}_{1}$ levels nor did it decrease the OVA-specific IgG $_{2 \mathrm{a}}$ levels in the anti-CD137 mAb-treated mice. Therefore, in our system, the IFN- $\gamma$-dependent part of the CD137-mediated protection does not act via inhibition of Th2 cytokines by a shift toward Th1. In contrast to the immunotherapy model of rheumatoid arthritis of Seo et al. (17) and the autoimmune disease model of Sun et al. (15), in which anti-IFN- $\gamma \mathrm{mAb}$ injection almost completely reversed the observed effects of targeting mice with anti-CD137 mAb alone, in our murine asthma model IFN- $\gamma$ is partly, but nowhere near completely, responsible for the CD137-mediated protection. Injection of blocking anti-IFN- $\gamma$ mAb reversed about $50 \%$ of the CD137mediated protection on airway inflammation and AHR and did not affect Th2 cytokine production and IgE synthesis. These observations show that other mechanisms must be involved in interfering with the CD137 effects in the allergic asthma model.

A possible role for $\mathrm{CD}^{+} \mathrm{T}$ cells in allergic asthma, especially in the regulation of AHR and IgE production, has been shown by several studies before $(24,40)$; nevertheless, the central role of $\mathrm{CD}^{+} \mathrm{T}$ cells in the murine asthma model is not questioned.

Also in our system, $\mathrm{CD}^{+} \mathrm{T}$ cells seem to play a role in controlling this disease by mediating partly the protective effects of antiCD137 mAb. Relevance of CD8 ${ }^{+} \mathrm{T}$ cells was already indirectly 

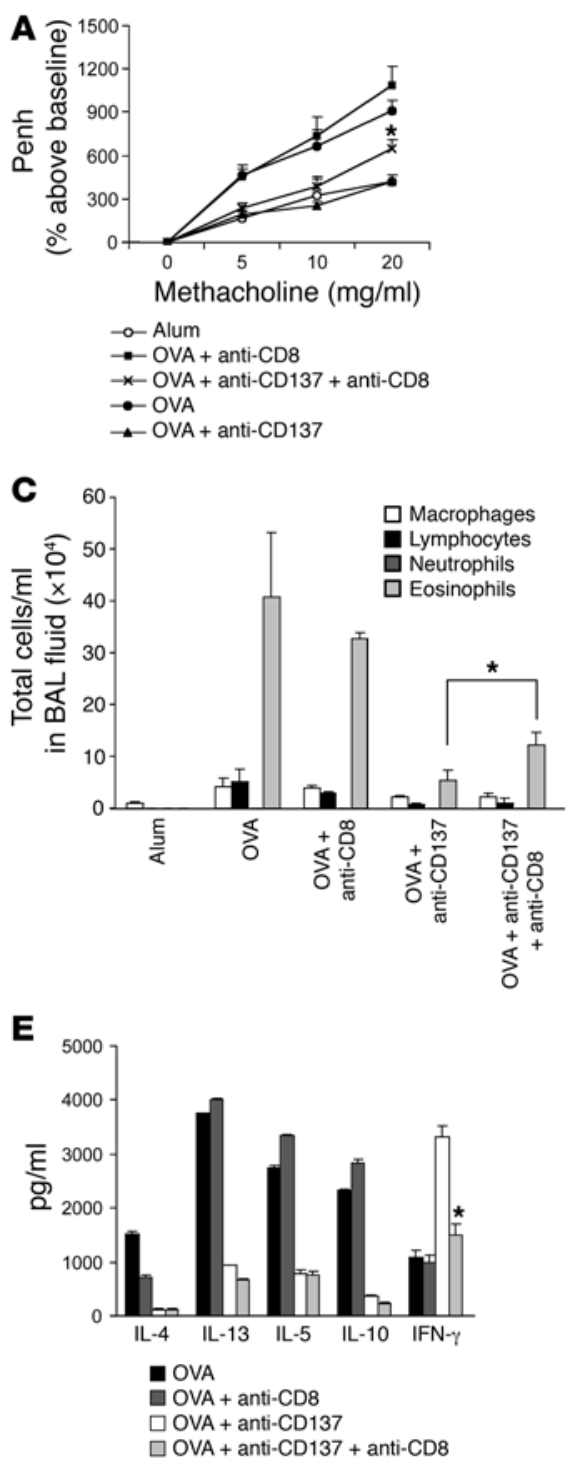


\section{Figure 6}

The anti-CD137 mAb-mediated therapeutic effect depends partly on CD8 ${ }^{+} \mathrm{T}$ cells and IFN- $\gamma$. (A) $\mathrm{CD}^{+}{ }^{+} \mathrm{T}$ cell depletion and (B) anti-IFN- $\gamma$ mAb application significantly increased AHR (measured on day 18) in anti-CD137 mAbtreated OVA-immunized BALB/c mice compared with control mice. (C) Depletion of CD8 ${ }^{+}$ T cells and (D) application of anti-IFN- $\gamma$ mAb before anti-CD137 mAb treatment increased the total cell number and the number of eosinophils in BAL fluid of anti-CD137-treated OVAimmunized mice. (E) Depletion of $\mathrm{CD}^{+} \mathrm{T}$ cells and (F) application of anti-IFN- $\gamma$ mAb had no effect on the decreased levels of Th2 cytokines after anti-CD137 mAb treatment, whereas the CD137-mediated increase in IFN- $\gamma$ production was abrogated. ${ }^{*} P<0.05$, OVA plus antiCD137 mAb versus OVA plus anti-CD137 mAb plus anti-CD8 mAb; ${ }^{* \star} P<0.001$, OVA plus anti-CD137 $\mathrm{mAb}$ versus OVA plus anti-CD137 $\mathrm{mAb}$ plus anti-IFN- $\gamma \mathrm{mAb}$ by Student's $t$ test. (A-D) Data are expressed as mean \pm SEM; $n \geq 9$ animals per group and data point for 3 independent experiments. ( $\mathbf{E}$ and $\mathbf{F}$ ) Data are expressed as mean \pm SEM; $n \geq 4$ animals for each group, and representative results from 1 of 3 experiments are shown. supported by FACS analysis revealing an almost 2-fold increase in $\mathrm{CD}^{+} \mathrm{T}$ cells by anti-CD $137 \mathrm{mAb}$ treatment. In contrast, the number of $\mathrm{CD} 4^{+} \mathrm{T}$ cells as well as that of $\mathrm{CD} 4^{+} \mathrm{CD} 25^{+} \mathrm{T}$ cells was not affected. These data suggest that, in our model, as in other models, anti-CD137 mAb preferentially stimulates $\mathrm{CD}^{+} \mathrm{T}$ cells (19). Depletion of $\mathrm{CD}^{+} \mathrm{T}$ cells significantly reduced the protective effect of anti-CD137 mAb on AHR and airway inflammation, by about $50 \%$, but did not affect cytokine production and Ig synthesis. The observation that the $\mathrm{CD}^{+} \mathrm{T}$ cell depletion resulted in effects very similar to those of blocking of IFN- $\gamma$ suggests that the anti-CD137 mAb-induced IFN- $\gamma$ production of CD8 ${ }^{+} \mathrm{T}$ cells - seen by intracellular FACS staining - might be responsible for the $\mathrm{CD}^{+} \mathrm{T}$ cell-mediated effects. Seo et al. (17) very recently showed in a murine model that CD137-mediated suppression of rheumatoid arthritis might be caused by a new population of $\mathrm{CD} 11 \mathrm{c}^{+} \mathrm{CD}^{+} \mathrm{T}$ cells. In their model, IFN- $\gamma$ produced by these cells suppressed $\mathrm{CD}^{+} \mathrm{T}$ cells through an indoleamine 2,3-dioxygenase-dependent mechanism. In our system we found a 3-fold increase of the $\mathrm{CD} 11 \mathrm{c}^{+} \mathrm{CD}^{+} \mathrm{T}$ cell population after anti-CD137 $\mathrm{mAb}$ treatment (data not shown). The role of these cells in our model is under investigation at the moment. Myers et al. (41) have also demonstrated suppressor function of $\mathrm{CD}^{+} \mathrm{T}$ cells after CD137 activation. In their system, CD137 and TLR ligands induced survival of specific effector $\mathrm{CD} 8^{+} \mathrm{T}$ cells with suppressive recall potential, which may explain the dual role that CD137 activation plays in mediating tumor clearance and prevention of autoimmune disease. The $\mathrm{CD}^{+} \mathrm{T}$ cells suppressed $\mathrm{CD}^{+} \mathrm{T}$ cell proliferation via a TGF- $\beta$-dependent mechanism, which was different from the mechanism found in the rheumatoid arthritis model of Seo et al. (17).

Nevertheless, our results demonstrate a role for $\mathrm{CD}^{+} \mathrm{T}$ cells in controlling AHR and eosinophilic inflammation and support the concept that inhibition of AHR and eosinophilic airway inflammation may be mediated partly by $\mathrm{CD}^{+} \mathrm{T}$ cells (42).

Since both depletion of CD8 ${ }^{+} \mathrm{T}$ cells and blocking of IFN- $\gamma$ reversed only about $50 \%$ of the CD137-mediated effects in our murine asthma model, other mechanisms must participate in the CD137-mediated protection in this Th2 cell-driven disease. We were interested in the role of $\mathrm{CD} 4^{+} \mathrm{T}$ cells since they are crucial in the pathogenesis of asthma. Biopsies and BAL fluids from patients with 


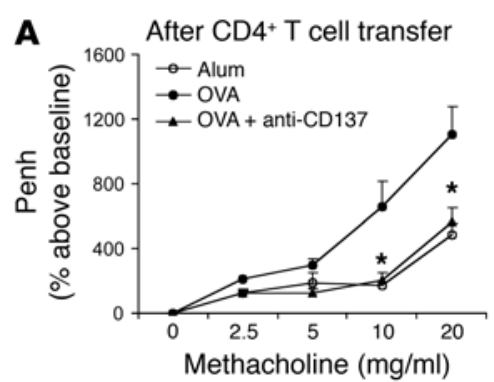

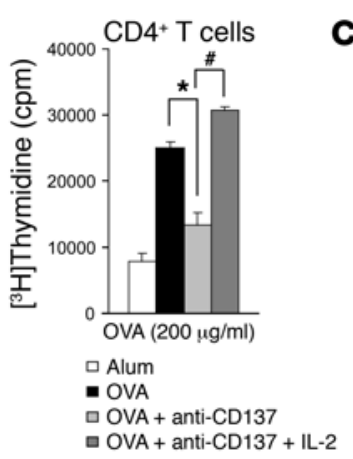



Figure 7

Anti-CD137 mAb induces CD4+ T cell anergy. BALB/c mice were immunized with OVA in Alum i.p. on day 1 and treated with anti-CD137 mAb or control mAb on day 3. Mice were sacrificed 5 days later, and CD4+ $T$ cells were isolated and restimulated in vitro with OVA. (A) Transfer of $\mathrm{CD}^{+} \mathrm{T}$ cells from OVA-immunized mice into SCID mice induced AHR in response to methacholine. This effect was abrogated when the OVAimmunized mice were treated with anti-CD137 mAb before cell transfer. Data are expressed as Penh (mean \pm SEM; $n \geq 7$ animals per group and data point, 2 independent experiments). (B) CD4+ $\mathrm{T}$ cells that were separated from OVA-immunized BALB/c mice proliferated in response to OVA. In contrast, CD4+ $T$ cells separated from OVA-immunized BALB/c mice that had received anti-CD137 mAb did not proliferate. CD4+ $T$ cells separated from OVA-immunized mice that had received anti-CD137 mAb did proliferate again when treated with IL-2. Data are expressed as mean $\mathrm{cpm} \pm \mathrm{SEM} ; n \geq 4$ animals for each group. Representative results from 1 of 2 experiments are shown. (C) IL-2 abrogated anti-CD137 $\mathrm{mAb}$-mediated inhibition of Th2 cytokine production in cell culture supernatants of OVA-immunized BALB/c mice. Data are expressed as mean \pm SEM; $n \geq 4$ animals for each group. Representative results from 1 of 2 experiments are shown. ${ }^{*}<0.05$, OVA versus OVA plus antiCD137 mAb; $P<<0.05$, OVA plus anti-CD137 mAb versus OVA plus anti-CD137 mAb plus IL-2 by Student's $t$ test.

asthma show increased amounts of activated T cells and of IL-4 and IL-5 $(34,43,44)$, and many animal models show that the initiation of the asthmatic reaction is dependent on T cells $(28,29)$, with the strongest evidence provided by experiments in which passive transfer of Th2 cell clones is able to induce AHR and inflammation in immunodeficient and immunocompetent mice $(23,30,31)$.

Proliferation assays with splenocytes derived from OVA-immunized and anti-CD137 mAb-treated BALB/c mice demonstrated almost complete inhibition of antigen-specific proliferation in response to anti-CD137 $\mathrm{mAb}$ treatment. This was surprising, since it has been shown before that once priming has been successfully completed in normal mice and $\mathrm{T}$ cells begin to activate and express CD137, administration of anti-CD137 mAb leads to amplification of proliferative responses and development of effector functions (45). In contrast, and perhaps in common with observations made in SLE (16), in our model of Th2 cell-mediated allergic asthma, anti-CD $137 \mathrm{mAb}$ administration inhibits OVA-induced proliferation as well as Th2 cytokine production, demonstrating that in this system $T$ cells do not become activated but become unresponsive to the allergen.

The important role of $\mathrm{CD}^{+} \mathrm{T}$ cell anergy in the anti-CD137 $\mathrm{mAb}$-mediated effect was demonstrated in a cell transfer experiment. While transfer of $\mathrm{CD}^{+} \mathrm{T}$ cells from OVA-immunized BALB/c mice into SCID mice resulted in significant AHR in the T cell recipients, this effect was almost abrogated when OVA-immunized mice were treated with anti-CD137 mAb before $\mathrm{CD}^{+} \mathrm{T}$ cell transfer. Furthermore, $\mathrm{CD}^{+} \mathrm{T}$ cells isolated from anti-CD137 $\mathrm{mAb}-$ treated mice did not proliferate after restimulation compared with $\mathrm{CD}^{+} \mathrm{T}$ cells from $\mathrm{BALB} / \mathrm{c}$ mice that had received control antibody. The inhibitory effect of anti-CD $137 \mathrm{mAb}$ on the production of the Th2 cytokines IL-4, IL-5, IL-10, and IL-13, which all play a crucial role in the development of AHR and inflammation in allergic asthma, is possibly due to CD137-induced anergy of OVA-specific $\mathrm{CD} 4^{+} \mathrm{T}$ cells. Our observation that $\mathrm{CD} 137$ activation induces anergy of $\mathrm{CD} 4^{+} \mathrm{T}$ cells in our model was supported by the finding that the unresponsive $\mathrm{CD}^{+} \mathrm{T}$ cells, derived from CD137 $\mathrm{mAb}-$ treated mice, started to proliferate again when IL-2 was added to the culture medium, a phenomenon typical for classical anergy. Moreover, the formerly unresponsive cells started to produce Th2 cytokines again to a level that was comparable to the level of the OVA-immunized control group. Coculture of unresponsive $\mathrm{CD}^{+}$ $\mathrm{T}$ cells with $\mathrm{CD}^{+}$effector cells did not result in inhibition of effector cells, as one would expect from $T$ regulatory cells, but further experiments to resolve the mechanism of the CD137 effect in our model are needed. Our data support the crucial role of anti-CD137 $\mathrm{mAb}$-induced $\mathrm{CD} 4^{+} \mathrm{T}$ cell anergy in the protective effects of stimulating this pathway in allergic asthma.

The anti-CD137 mAb-mediated decrease in B cells was associated with a significant inhibition of $\operatorname{IgE}$ and $\operatorname{IgG}_{1}$ serum levels. This might partly be due to missing $\mathrm{T}$ cell help in anti-CD137 $\mathrm{mAb}$-treated OVA-sensitized mice, since it has been shown that agonistic anti-CD137 mAb application abrogated $\mathrm{T}$ cell-dependent antibody responses via the induction of Th cell anergy (11). In a model of spontaneous autoimmune disease, it was argued that the increased IFN- $\gamma$ levels induced by anti-CD137 $\mathrm{mAb}$ application are involved in B cell reduction, since IFN- $\gamma$ is a potent activator of macrophages (46) and, in the presence of IFN- $\gamma$, macrophages greatly enhance B cell apoptosis (15). In our system, blocking of IFN- $\gamma$ or depletion of IFN- $\gamma$-producing CD8 ${ }^{+}$ $\mathrm{T}$ cells normalized the CD137-mediated reduction in the number of CD19+ $\mathrm{B}$ cells but did not change CD137-mediated effects on Ig synthesis (data not shown). These observations favor the mechanism of missing $\mathrm{T}$ cell help for $\mathrm{B}$ cells to explain reduced Ig levels after anti-CD137 mAb treatment.

Our data indicate that - in contrast to models of tumor (12, $13)$ or virus defense (14) and Th1-mediated autoimmune disease $(15,16)$ - the CD137-mediated protective effects in our Th2-mediated murine asthma model seem to depend only partly on $\mathrm{CD}^{+}$ $\mathrm{T}$ cells and IFN- $\gamma$, while anergy of $\mathrm{CD}^{+} \mathrm{T}$ cells seems also to play an important role. It is unclear whether these two mechanisms are 
related to each other. Indirect induction of Th cell anergy through suppressor cells is one possible explanation. For instance, Myers et al. (41) showed that rescued $\mathrm{CD}^{+} \mathrm{T}$ cells suppressed $\mathrm{CD}^{+} \mathrm{T}$ cell proliferation via a TGF- $\beta$-dependent mechanism. However, our experiments did not provide convincing evidence for a similar mechanism. In our model, we did not see any effect on TGF- $\beta$ or IL-10 (data not shown), and the protective effects of antiCD137 mAb on IgE levels and Th2 cytokine production remained unchanged after $\mathrm{CD}^{+} \mathrm{T}$ cell depletion or inhibition of IFN- $\gamma$. In the murine asthma model, the anti-CD137 mAb-induced CD4 ${ }^{+}$ $T$ cell anergy seems to be a second mechanism not dependent on $\mathrm{CD}^{+} \mathrm{T}$ cells. As $\mathrm{CD}^{+} \mathrm{T}$ cells express CD137, it is conceivable that the antibody directly induces anergy of these cells. As demonstrated before (19), although anti-CD137 mAb profoundly costimulates $\mathrm{CD}^{+} \mathrm{T}$ cells to proliferate, they marginally activate $\mathrm{CD}^{+} \mathrm{T}$ cells. Furthermore, the same study demonstrated that there were qualitative and quantitative differences in protein tyrosine phosphorylation between $\mathrm{CD}^{+}$and $\mathrm{CD}^{+} \mathrm{T}$ cells, suggesting different effects of anti-CD137 mAb on these cell populations. However, the mechanisms of anti-CD137 mAb in inhibiting the asthma phenotype remain to be fully elucidated.

In conclusion, the findings reported here show, for the first time to our knowledge, that CD137 plays an interesting and potentially important role in inhibition of the Th2 cell-mediated allergic immune response.

Our data indicate that strategies aimed at stimulation of CD137 may represent a therapeutic target during allergic inflammatory responses and other disorders characterized by inappropriate $\mathrm{T}$ cell activation.

\section{Methods}

Animals. Female BALB/cByJ mice and histocompatible C.B-17Icr ${ }^{\text {scid/scid }}$ mice (6-8 weeks of age) were obtained from the Jackson Laboratory and bred and maintained in our animal facility at the Biocenter in Halle/ Saale, Germany. All animal experiments involved groups of 4-6 mice and were performed according to institutional and state guidelines. The Committee on Animal Welfare of Saxony-Anhalt approved animal protocols used in this study.

Immunization and antibody treatments. For the prevention protocol, mice were immunized with OVA ( $20 \mu \mathrm{g}$; Sigma-Aldrich) adsorbed to $2 \mathrm{mg}$ of an aqueous solution of aluminum hydroxide and magnesium hydroxide (Alum; Fischer Scientific International) i.p. on days 1 and 14, followed by $20 \mu \mathrm{g}$ OVA in $40 \mu \mathrm{l}$ normal saline given intranasally on days $14-16,28-30$, and 42-44. Control mice received Alum i.p. and normal saline intranasally. Anti-CD137 mAb (3H3, rat IgG $\mathrm{I}_{\mathrm{a}}$ anti-mouse CD137 mAb, $\left.200 \mu \mathrm{g}\right)$ or control mAb (9D6, rat IgG $\mathrm{Ig}_{\mathrm{a}}$ anti-human CD137 mAb, $200 \mu \mathrm{g}$ ) was injected i.p. 1 day before the first OVA immunization. AHR was measured on days 17, 31 , and 45 , and mice were sacrificed on day 18 or 46 . For reversal protocol $I$, mice were immunized with OVA $(40 \mu \mathrm{g})$ in Alum i.p. on day 1 followed by OVA $(20 \mu \mathrm{g})$ in normal saline intranasally on days $8-10$. Control mice received Alum i.p. and normal saline intranasally. To confirm the induction of AHR by OVA sensitization, AHR was measured the following day. Anti-CD137 mAb or control mAb was injected i.p. 12 hours after AHR measurement on day 11. Intranasal OVA challenge was repeated on days 15-17, and AHR was measured on day 18. Mice were sacrificed the following day. For $\mathrm{CD}^{+} \mathrm{T}$ cell depletion, anti-CD8 mAb (YTS 169.4, rat $\mathrm{IgG}_{2 \mathrm{~b}}$ anti-mouse CD8 $\mathrm{mAb}, 100 \mu \mathrm{g}$ ) was injected on days 8,9 , 14, and 17. Flow cytometric analysis on days 10 and 19 showed $99 \%$ depletion of $\mathrm{CD}^{+} \mathrm{T}$ cells. Anti-IFN- $\gamma$ mAb (XMG1.2, rat IgG $_{1}$ anti-mouse IFN- $\gamma$ mAb, $10 \mu \mathrm{g}$; eBioscience) was injected on days 11 and 14 (47). In reversal protocol II, we tested the effect of anti-CD137 mAb on the fully established asthma phenotype. For this purpose, mice were immunized with OVA i.p. and afterward challenged several times intranasally during the following 31 days (days 8-10, 14-16, 21-23, and 29-31). Lung function was measured on day 32. Anti-CD137 mAb was injected the same day, followed by further intranasal challenges with OVA (days 39-41). AHR was measured on day 42 , and mice were sacrificed the following day (Figure 1).

Measurement of AHR. Airway responsiveness was assessed by methacholineinduced airflow obstruction in conscious mice placed in a whole-body plethysmograph (model PLT UNR MS; emka TECHNOLOGIES) as described previously (23). Pulmonary resistance and dynamic compliance were measured after challenge with aerosolized methacholine in orotracheally intubated, spontaneously breathing mice as described previously $(48,49)$.

Collection of BAL fluid. Animals were sacrificed by $\mathrm{CO}_{2}$ asphyxiation 1 day after the last AHR measurement. The trachea was cannulated, and the right lung was lavaged 3 times with $400 \mu 10.9 \% \mathrm{NaCl}$. Cells in the lavage fluid were counted using a hemocytometer, and BAL cell differentials were determined on slide preparations stained with May-GrünwaldGiemsa (Merck) on blinded samples by an independent investigator. At least 200 cells were differentiated by light microscopy based on conventional morphologic criteria.

In vitro proliferation and cytokine production. Splenocytes $\left(5 \times 10^{6}\right.$ cells per well) were isolated and restimulated in vitro with $0.2-200 \mu \mathrm{g} / \mathrm{ml} \mathrm{OVA}$ in culture medium (RPMI medium supplemented with $10 \%$ FCS, $100 \mathrm{U} / \mathrm{ml}$ penicillin, $100 \mu \mathrm{g} / \mathrm{ml}$ streptomycin) 1 day after airway function test. Fortyeight hours later, cultures were pulsed with $0.25 \mu \mathrm{Ci}$ of $\left[{ }^{3} \mathrm{H}\right] \mathrm{TdR}$ thymidine for 18 hours, and incorporated activity was measured in a scintillation counter (Wallac MicroBeta Trilux; PerkinElmer).

Cytokines were measured in supernatants from restimulated spleen or lung cells after 3 days using DuoSet ELISA kits (R\&D Systems) according to the manufacturer's instructions.

Lung histology and computer-based quantification of inflammation, mucus production, and ECM deposition. Left lungs were fixed in 10\% formalin and stained with H\&E (Merck) or with Alcian blue-PAS (Sigma-Aldrich). For quantification and objective evaluation of the degree of histological inflammation and mucus production, lung sections were scanned with a digital camera (Visitron Systems; 5 shots per lung) and analyzed with HistoClick software based on morphometric image analysis developed in our laboratory. Total matrix deposition was assessed on MSB-stained sections (27). All slides were examined by 2 independent investigators in a random blinded fashion. Digital photographs of 4 bronchioles per tissue section were taken and analyzed with HistoClick software for ECM deposition.

Collagen analysis. Collagen content was measured in lung tissue homogenates by a biochemical assay according to the manufacturer's instructions (Sircol collagen assay; Biocolor). Lung tissue (100 mg) was homogenized in $1 \mathrm{ml}$ 0.5-M acetic acid containing $1 \mathrm{mg}$ pepsin (SigmaAldrich) per $10 \mathrm{mg}$ tissue residue. Samples were incubated overnight at $4^{\circ} \mathrm{C}$ with stirring and centrifuged, and the supernatant was assayed.

Transfer of cells. BALB/c mice were immunized with OVA $(20 \mu \mathrm{g})$ in Alum i.p. on day 1 followed by i.p. injection of anti-CD137 mAb (3H3, 200 $\mu \mathrm{g})$ or control mAb (9D6, $200 \mu \mathrm{g})$ on day 3. One group of mice received Alum instead of OVA and no mAbs. Five days later, $\mathrm{CD} 4^{+} \mathrm{T}$ cells were isolated by magnetic cell sorting ( $\mathrm{CD}^{+} \mathrm{T}$ cell isolation kit; Miltenyi Biotec) from $B A L B / c$ mice that had received Alum, OVA plus control $m A b$, or OVA plus anti-CD137 mAb. CD4+ T cells $\left(2.5 \times 10^{6}\right)$ were transferred i.p. into histocompatible SCID mice. SCID mice received OVA intranasally 1 day before and 2 days after cell transfer. AHR was measured the following day. $\mathrm{CD}^{+} \mathrm{T}$ cells $\left(1 \times 10^{6}\right)$ were not used for cell transfer but were cultured with $2.5 \times 10^{6}$ irradiated splenocytes from BALB/c mice and restimulated with OVA. To test whether unresponsive $\mathrm{CD} 4^{+} \mathrm{T}$ cells 
could be reactivated, some of the cells were cocultured with human IL-2 (20 U/ml; Roche Diagnostics Corp.) before proliferation and cytokine production in the culture supernatant were measured.


els were measured by sandwich ELISA according to a standard protocol. Briefly, 96-well microtiter plates (Nunc) were coated overnight with 10 $\mu \mathrm{g} / \mathrm{ml}$ OVA diluted in bicarbonate buffer ( $\mathrm{pH}$ 9.6). After washing and blocking of plates, samples were incubated for 2 hours. Subsequently, 96-well plates were washed, and HRP-conjugated goat anti-mouse IgE antibody (Bethyl Laboratories Inc.) was added. Tetramethylbenzidine was used as substrate, and the OD was determined at $450 \mathrm{~nm}$ using a BioRad microplate reader (Bio-Rad Laboratories). The titer was calculated by logarithmic regression as the reciprocal dilution of the sera, where the extinction was 2 -fold the background extinction.

Flow cytometric analysis. Flow cytometric analysis was performed using FITC-, PE-, or peridinin chlorophyll protein-Cy5.5-conjugated $\mathrm{mAb}$ against mouse CD3, CD4, CD8 $\alpha$, and CD19 (BD Biosciences - Pharmingen). Cells $\left(1 \times 10^{6}\right)$ were preincubated with $2.4 \mathrm{G} 2 \mathrm{mAb}(10 \mu \mathrm{g} / \mathrm{ml})$ to block Fc $\gamma \mathrm{R}$, and then incubated with the relevant $\mathrm{mAbs}$ for 45 minutes at $4{ }^{\circ} \mathrm{C}$. Cells were washed twice with $1 \%$ BSA in PBS and analyzed by FACScan (BD Biosciences - Pharmingen). For intracellular FACS analysis, cells were stimulated with phorbol ester $(0.1 \mu \mathrm{g} / \mathrm{ml})$ and ionomycin $(0.5 \mu \mathrm{g} / \mathrm{ml}$; both from SigmaAldrich) for 6 hours. Brefeldin A (GolgiPlug; BD Biosciences) was added for the last 4 hours. Cells were washed and stained with anti-CD4 $\mathrm{mAb}$ and
anti-CD8 mAb, permeabilized with Cytofix/Cytoperm buffer (BD Biosciences), and then incubated with PE-labeled anti-IFN- $\gamma \mathrm{mAb}$.

Statistics. Two-tailed Student's $t$ test was used to determine the statistical significance of differences between groups. $P$ values of less than 0.05 were considered statistically significant.

\section{Acknowledgments}

This work was supported by the Deutsche Forschungsgemeinschaft (HA2799-3-1) and the Bundesministerium für Bildung und Forschung (01 ZZ 0109). We thank Jana Bergmann and Marita Reiprich for excellent technical assistance, Ingo Hohmann and Wiebke Scherf for developing the software to analyze the lung tissues, and Reinhard Gerlach (Department of Radiotherapy, Martin Luther University, Halle, Germany) for the opportunity to irradiate splenocytes.

Received for publication November 1, 2004, and accepted in revised form January 17, 2006.

Address correspondence to: Gesine Hansen, Medizinische Hochschule Hannover, Department of Pediatrics, Division of Pulmonology and Neonatology, Carl-Neuberg-Str. 1, 30625 Hannover, Germany. Phone: 0049-511-532-9138; Fax: 0049-511-532-9125; E-mail: hansen.gesine@mh-hannover.de.
1. Umetsu, D.T., McIntire, J.J., Akbari, O., Macaubas, C., and DeKruyff, R.H. 2002. Asthma: an epidemic of dysregulated immunity. Nat. Immunol. 3:715-720.

2. Schwartz, J.C., Zhang, X., Nathenson, S.G., and Almo, S.C. 2002. Structural mechanisms of costimulation. Nat. Immunol. 3:427-434.

3. Harding, F.A., McArthur, J.G., Gross, J.A., Raulet, D.H., and Allison, J.P. 1992. CD28-mediated signalling co-stimulates murine $\mathrm{T}$ cells and prevents induction of anergy in T-cell clones. Nature. 356:607-609.

4. Rudd, C.E., and Schneider, H. 2003. Unifying concepts in CD28, ICOS and CTLA4 co-receptor signalling. Nat. Rev. Immunol. 3:544-556.

5. Coyle, A.J., and Gutierrez-Ramos, J.C. 2004. The role of ICOS and other costimulatory molecules in allergy and asthma. Springer Semin. Immunopathol. 25:349-359.

6. Croft, M. 2003. Co-stimulatory members of the TNFR family: keys to effective T-cell immunity? Nat. Rev. Immunol. 3:609-620.

7. Watts, T.H., and DeBenedette, M.A. 1999. T cell co-stimulatory molecules other than CD28. Curr. Opin. Immunol. 11:286-293.

8. Pollok, K.E., et al. 1993. Inducible T cell antigen 4-1BB. Analysis of expression and function. J. Immunol. 150:771-781.

9. DeBenedette, M.A., et al. 1995. Role of 4-1BB ligand in costimulation of $\mathrm{T}$ lymphocyte growth and its upregulation on M12 B lymphomas by cAMP. J. Exp. Med. 181:985-992.

10. Hurtado, J.C., Kim, Y.J., and Kwon, B.S. 1997. Signals through 4-1BB are costimulatory to previously activated splenic $\mathrm{T}$ cells and inhibit activationinduced cell death. J. Immunol. 158:2600-2609.

11. Mittler, R.S., Bailey, T.S., Klussman, K., Trailsmith, M.D., and Hoffmann, M.K. 1999. Anti-4-1BB monoclonal antibodies abrogate $\mathrm{T}$ cell-dependent humoral immune responses in vivo through the induction of helper T cell anergy. J. Exp. Med. 190:1535-1540.

12. Melero, I., et al. 1997. Monoclonal antibodies against the 4-1BB T-cell activation molecule eradicate established tumors. Nat. Med. 3:682-685.

13. Ye, Z., et al. 2002. Gene therapy for cancer using single-chain Fv fragments specific for 4-1BB. Nat. Med. 8:343-348.

14. Halstead, E.S., Mueller, Y.M., Altman, J.D., and Katsikis, P.D. 2002. In vivo stimulation of CD137 broadens primary antiviral CD8+ $\mathrm{T}$ cell responses. Nat. Immunol. 3:536-541.

15. Sun, Y., et al. 2002. Costimulatory molecule-targeted antibody therapy of a spontaneous autoimmune disease. Nat. Med. 8:1405-1413.

16. Foell, J., et al. 2003. CD137 costimulatory T cell receptor engagement reverses acute disease in lupus-prone NZB x NZW F1 mice. J. Clin. Invest. 111:1505-1518. doi:10.1172/JCI200317662.

17. Seo, S.K., et al. 2004. 4-1BB-mediated immunotherapy of rheumatoid arthritis. Nat. Med. 10:1088-1094.

18. Foell, J.L., et al. 2004. Engagement of the CD137 (4-1BB) costimulatory molecule inhibits and reverses the autoimmune process in collageninduced arthritis and establishes lasting disease resistance. Immunology. 113:89-98.

19. Shuford, W.W., et al. 1997. 4-1BB costimulatory signals preferentially induce CD $8+\mathrm{T}$ cell proliferation and lead to the amplification in vivo of cytotoxic $T$ cell responses. J. Exp. Med. 186:47-55.

20. Kim, Y.J., Kim, S.H., Mantel, P., and Kwon, B.S 1998. Human 4-1BB regulates CD28 co-stimulation to promote Th1 cell responses. Eur. J. Immunol. 28:881-890.

21. Vinay, D.S., et al. 2004. CD137-deficient mice have reduced NK/NKT cell numbers and function, are resistant to lipopolysaccharide-induced shock syndromes, and have lower IL-4 responses. J. Immunol. 173:4218-4229.

22. Heinisch, I.V., Bizer, C., Volgger, W., and Simon, H.U. 2001. Functional CD137 receptors are expressed by eosinophils from patients with IgEmediated allergic responses but not by eosinophils from patients with non-IgE-mediated eosinophilic disorders. J. Allergy Clin. Immunol. 108:21-28.

23. Hansen, G., Berry, G., DeKruyff, R.H., and Umetsu, D.T. 1999. Allergen-specific Th1 cells fail to counterbalance Th2 cell-induced airway hyperreactivity but cause severe airway inflammation. J. Clin. Invest. 103:175-183.

24. Hansen, G., Yeung, V.P., Berry, G., Umetsu, D.T., and DeKruyff, R.H. 2000. Vaccination with heat- killed Listeria as adjuvant reverses established allergen-induced airway hyperreactivity and inflammation: role of CD8+ T cells and IL-18. J. Immunol. 164:223-230.

25. Zhu, G., et al. 2001. Progressive depletion of peripheral B lymphocytes in 4-1BB (CD137) ligand/I-Ealphatransgenic mice. J. Immunol. 167:2671-2676.

26. Lendrum, A.C., Fraser, D.S., Slidders, W., and Henderson, R. 1962. Studies on the character and staining of fibrin. J. Clin. Pathol. 15:401-413.

27. Humbles, A.A., et al. 2004. A critical role for eosinophils in allergic airways remodeling. Science. 305:1776-1779.

28. Gavett, S.H., Chen, X., Finkelman, F., and WillsKarp, M. 1994. Depletion of murine CD4+ T lymphocytes prevents antigen-induced airway hyperreactivity and pulmonary eosinophilia. Am. J. Respir. Cell Mol. Biol. 10:587-593.

29. Wills-Karp, M. 1999. Immunologic basis of antigen-induced airway hyperresponsiveness. Annu. Rev. Immunol. 17:255-281.

30. Cohn, L., Tepper, J.S., and Bottomly, K. 1998. IL-4independent induction of airway hyperresponsiveness by Th2, but not Th1, cells. J. Immunol. 161:3813-3816.

31. Randolph, D.A., Carruthers, C.J., Szabo, S.J., Murphy, K.M., and Chaplin, D.D. 1999. Modulation of airway inflammation by passive transfer of allergen-specific Th 1 and Th 2 cells in a mouse model of asthma. J. Immunol. 162:2375-2383.

32. Hansen, G., Jin, S., Umetsu, D.T., and Conti, M. 2000. Absence of muscarinic cholinergic airway responses in mice deficient in the cyclic nucleotide phosphodiesterase PDE4D. Proc. Natl. Acad. Sci. U. S. A. 97:6751-6756

33. Hansen, G., et al. 2000. CD4(+) T helper cells engineered to produce latent TGF- $\beta 1$ reverse allergeninduced airway hyperreactivity and inflammation. J. Clin. Invest. 105:61-70.

34. Robinson, D.S., et al. 1992. Predominant TH2like bronchoalveolar T-lymphocyte population in atopic asthma. N. Engl. J. Med. 326:298-304.

35. Herrick, C.A., and Bottomly, K. 2003. To respond or not to respond: T cells in allergic asthma. Nat. Rev. Immunol. 3:405-412.

36. Li, X.M., et al. 1996. Mucosal IFN-gamma gene 
transfer inhibits pulmonary allergic responses in mice. J. Immunol. 157:3216-3219.

37. Lack, G., et al. 1996. Nebulized IFN-gamma inhibits the development of secondary allergic responses in mice. J. Immunol. 157:1432-1439.

38. Benjaponpitak, S., et al. 1999. The kinetics of change in cytokine production by CD4 $\mathrm{T}$ cells during conventional allergen immunotherapy. J. Allergy Clin. Immunol. 103:468-475.

39. Mosmann, T.R., and Coffman, R.L. 1989. TH1 and TH2 cells: different patterns of lymphokine secretion lead to different functional properties. Annu. Rev. Immunol. 7:145-173.

40. Hsu, C.H., et al. 1996. Immunoprophylaxis of allergen-induced immunoglobulin E synthesis and airway hyperresponsiveness in vivo by genetic immunization. Nat. Med. 2:540-544.
41. Myers, L., Takahashi, C., Mittler, R.S., Rossi, R.J., and Vella, A.T. 2003. Effector CD8 T cells possess suppressor function after 4-1BB and Toll-like receptor triggering. Proc. Natl. Acad. Sci. U. S. A. 100:5348-5353.

42. Miyahara, N., et al. 2004. Effector CD8+ T cells mediate inflammation and airway hyper-responsiveness. Nat. Med. 10:865-869.

43. Chung, K.F., and Barnes, P.J. 1999. Cytokines in asthma. Thorax. 54:825-857.

44. Busse, W.W., and Lemanske, R.F., Jr. 2001. Asthma. N. Engl. J. Med. 344:350-362.

45. Takahashi, I., Iijima, H., Katashima, R., Itakura, M., and Kiyono, H. 1999. Clonal expansion of CD4+ TCRbetabeta $+\mathrm{T}$ cells in TCR alpha-chaindeficient mice by gut-derived antigens. J. Immunol. 162:1843-1850.
46. Ding, A.H., Nathan, C.F., and Stuehr, D.J. 1988. Release of reactive nitrogen intermediates and reactive oxygen intermediates from mouse peritoneal macrophages. Comparison of activating cytokines and evidence for independent production. J. Immunol. 141:2407-2412.

47. Mattner, F., Di Padova, K., and Alber, G. 1997. Interleukin-12 is indispensable for protective immunity against Leishmania major. Infect. Immun. 65:4378-4383.

48. Glaab, T., et al. 2004. Repetitive measurements of pulmonary mechanics to inhaled cholinergic challenge in spontaneously breathing mice. J. Appl. Physiol. 97:1104-1111.

49. Ruckert, R., et al. 2005. Blocking IL-15 prevents the induction of allergen-specific $\mathrm{T}$ cells and allergic inflammation in vivo. J. Immunol. 174:5507-5515. 